\title{
Expression of peptide receptors in human endocrine tumours of the pancreas
}

\author{
C Tang, I Biemond, C B H W Lamers
}

\begin{abstract}
Background-Gut peptides are known to influence hormone release and growth of endocrine tumours of the pancreas. Although information on somatostatin receptors has been provided recently, little is known on the receptor status of other gastrointestinal hormones in such tumours.
\end{abstract}

Aims-To analyse the spectrum of gut hormone receptors on endocrine tumours of pancreas.

Subjects-Four types of endocrine tumours from eight patients.

Methods-The receptors for bombesin, secretin, vasoactive intestinal peptide, cholecystokinin, and somatostatin have been visualised and quantified with storage phosphor autoradiography.

Results-Bombesin receptors were present in all five gastrinomas and two primary VIPomas. Secretin receptors were expressed in four primary gastrinomas and one primary VIPoma from pancreas. Vasoactive intestinal peptide receptors were identified in four primary gastrinomas and all VIPomas. Furthermore, all VIPomas expressed cholecystokinin-B (gastrin) receptors, whereas, gastrinomas did not contain cholecystokinin-B receptors. The receptors for somatostatin were detected in all gastrinomas and VIPomas. Both somatostatinoma and glucagonoma were negative for all five types of peptide receptors studied.

Conclusions-Besides somatostatin receptors, most of gastrinomas and VIPomas also express receptors for bombesin, secretin, and vasoactive intestinal peptide. (Gut 1997; 40: 267-271)

Keywords: gut hormone receptor, endocrine tumour, pancreas.

Endocrine tumours of the pancreas are classified according to the type of clinical syndrome they present. Apart from the morbidity due to hypersecretion of hormones, the tumour may lead to death of the patient due to its malignant potential. As most tumours are malignant, with metastases present at the time of diagnosis, complete surgical excision is rarely feasible. ${ }^{12}$ Other treatment modalities are often applied. Chemotherapy or interferon therapy has low efficacy and only induce transient remissions. ${ }^{2}{ }^{3}$ Hormonal therapy with somatostatin or its analogues is often attempted in such patients. ${ }^{34}$ However, little is known on the receptor status of other gastrointestinal hormones that may influence tumour function and growth.

Increasing evidence exists that growth and proliferation as well as the functional properties of various tumour cells are modulated by gut peptides. Some investigations on tumour biology of gastrinomas have shown that secretin and bombesin stimulate, while somatostatin inhibits gastrin release from dispersed or cultured gastrinoma cells. ${ }^{5-8}$ These data suggest that secretin, bombesin, and somatostatin act directly on gastrinoma cells to stimulate or inhibit gastrin release. With respect to somatostatin receptor, Reubi et $a l^{9}$ have identified these receptors not only in gastrinoma but also in some cases of VIPoma, glucagonoma, and insulinoma. On the basis of this, the somatostatin analogue octreotide has been shown to be of benefit in the scintigraphic localisation and treatment of clinical syndromes caused by hypersecretion of those hormones. ${ }^{410} 11$ More recent studies suggest that vasoactive intestinal peptide (VIP) also regulates the growth and function of tumour cells. ${ }^{12}$ Receptors for VIP have been detected in pancreatic carcinoma cell lines. ${ }^{13}{ }^{14}$ In vivo scanning with radioiodinated VIP has successfully shown the tumour masses in patients with insulinoma. ${ }^{15}$ Although cholecystokinin is the most important enterohormone affecting pancreatic carcinogenesis, ${ }^{16}$ up to now, no studies on the effect of cholecystokinin or cholecystokinin receptor antagonists on endocrine tumours of the pancreas have been reported. Therefore, except for the somatostatin receptor, the peptide receptor status of endocrine tumours of the pancreas is largely unknown. A better knowledge of peptide receptors in these neoplasms may be helpful to understand the behaviour of the tumours and to widen the ways for diagnosis, scintigraphic localisation, and treatment.

To evaluate the gut peptide receptor status in endocrine tumours of the pancreas, we visualised and characterised receptors from secretin, bombesin, VIP, cholecystokinin, and somatostatin in tissue sections from gastrinomas, VIPomas, somatostatinomas, and a glucagonoma. The visualisation and quantification of peptide receptor in this study were accomplished with storage phosphor autoradiography. This new technique requires no chemical development and can be erased and reused. When compared with film autoradiography, storage phosphor autoradiography is a faster technique for localising and quantifying peptide receptors in tissue sections and easier to perform because of its higher sensitivity and wider (covering five orders magnitude) linear dynamic range. ${ }^{17}$ 


\section{Methods}

Eight pancreatic endocrine tumours were obtained at surgery from two men and six women (Table I). The average age was 47 (14) (mean (SD)) years. Immediately after removal of the tumour, one part was used for histological examination, while the other part was radidly frozen at $-80^{\circ} \mathrm{C}$. Diagnoses were established on the basis of clinical data, histological and immunohistochemical examination (gastrin, pancreatic polypeptide, glucagon, somatostatin, and VIP), and peptide measurement in tumour extracts and plasma by radioimmunoassay. Tissue sections $(10 \mu \mathrm{m})$ were cut at $-20^{\circ} \mathrm{C}$ using a cryostat microtome, mounted onto gelatin coated slides and dried overnight at $-80^{\circ} \mathrm{C}$.

Cholecystokinin-33 was acylated with ${ }^{125}$ I-labelled Bolton-Hunter reagent as described by Jansen and Lamers. ${ }^{18}$ The specific activity was about $2200 \mathrm{Ci} / \mathrm{mmol}$. Synthetic Tyr ${ }^{1}-S S T-14$ or Tyr-B-ala-secretin and VIP-28 were iodinated using the Chloramine-T oxidation method, ${ }^{19}{ }^{20}$ which yielded a specific activity of $2200 \mathrm{Ci} / \mathrm{mmol}$ for ${ }^{125} \mathrm{I}_{-} \mathrm{Tyr}^{1}$ somatostatin-14, ${ }^{125} \mathrm{I}-\mathrm{Tyr}-\mathrm{B}$-ala-secretin, and $4000 \mathrm{Ci} / \mathrm{mmol}$ for ${ }^{125} \mathrm{I}-\mathrm{VIP}-28$. ${ }^{125} \mathrm{I}-\mathrm{Tyr}^{4}-$ -bombesin with a specific activity of 2200 $\mathrm{Ci} / \mathrm{mmol}$ was purchased from New England Nuclear, Boston, MA, USA.

Binding of ${ }^{125} \mathrm{I}-\mathrm{BH}$-cholecystokinin-33 to tissue sections was carried out essentially as described previously. ${ }^{21} \mathrm{The}^{125} \mathrm{I}-\mathrm{Tyr}^{4}$-bombesin and ${ }^{125}$ I-Tyr-B-ala-secretin and ${ }^{125}$ I-VIP-28 binding assays used the same procedure as for ${ }^{125} \mathrm{I}-\mathrm{BH}$-cholecystokinin, except that the $\mathrm{pH}$ of the pre-incubation, incubation, and washing buffers was 6.5 or 7 instead of 6.0 . Binding of ${ }^{125}$ I-Tyr ${ }^{1}$-somatostatin-14 to tissue sections was performed according to Leroux et al. ${ }^{22}$ The concentration of the labelled secretin, bombesin, VIP, cholecystokinin, and somatostatin was $100 \mathrm{pM}$. Alternate slides were incubated with addition of non-radioactive 1 $\mu \mathrm{M}$ of the corresponding peptides to determine the extent of non-specific binding. Specific bindings for secretin, bombesin, VIP, cholecystokinin, and somatostatin were $68 \%$, $75 \%, 70 \%, 85 \%$, and $60 \%$ of total binding, respectively, in normal rat pancreas as positive control. The sections were subsequently washed three times for five minutes at $4^{\circ} \mathrm{C}$ in $50 \mathrm{mM}$ TRIS buffer containing $5 \mathrm{~g} / 1$ bovine plasma albumin.

The dried tissue sections and one slide with two dried drops of $10 \mu l 100 \mathrm{pM}$ labelled peptide for standardisation were placed in a storage phosphor cassette for 24 hours at $22^{\circ} \mathrm{C}$. The latent image stored in the storage phosphor screen was scanned by the PhosphorImager and the data were processed with ImageQuant software (Molecular Dynamics, Sunnyvale, CA, USA). Receptor binding unit was normalised to fmol of radioactive peptides bound per mg of protein. ${ }^{7}$

To determine the subtype of cholecystokinin receptors on VIPomas, we studied the abilities of cholecystokinin-A and cholecystokinin-B receptor agonists (cholecystokinin-8 and gastrin) and antagonists (lorglumide, gifts from Rotta Research Laboratories, Milan, Italy and L365, 260, obtained from Merck Sharp and Dohme Research Laboratory, Division of Merk and Co, Rahway, NJ, USA) to inhibit binding of labelled cholecystokinin under identical conditions. Binding parameters (Kda (dissociation constant) and Bmax (maximum binding capacity)) were determined for each binding site by using a non-linear least squares curve fitting program (LIGAND) ${ }^{23}$ Significance of differences was analysed using Student's $t$ test.

\section{Results}

Table I summarises the clinical, histological, immunohistochemical, and extract data of the tumours. The Table further shows the results regarding incidence of receptors for secretin, bombesin, VIP, cholecystokinin, and somatostatin in gastrinomas, VIPomas, somatostatinomas, and a glucagonoma from eight patients.

It can be seen that bombesin and somatostatin receptors are present in all gastrinomas. Secretion and VIP receptors were found in all primary gastrinomas but they were absent in a metastasis to the liver. No cholecystokinin receptors were detected in any of the gastrinomas. All VIPomas in this study expressed receptors for somatostatin, VIP, and cholecystokinin. The two primary VIPomas expressed

TABLE I Individual data of eight patients with pancreatic endocrine tumours and the receptor quantification in tissue section of the tumours

\begin{tabular}{|c|c|c|c|c|c|c|c|c|c|c|c|c|c|c|}
\hline \multirow{2}{*}{$\begin{array}{l}\text { Case } \\
\text { no }\end{array}$} & \multirow[b]{2}{*}{ Tumour site } & \multirow{2}{*}{$\begin{array}{l}\text { Clinical } \\
\text { syndrome }\end{array}$} & \multirow{2}{*}{$\begin{array}{l}\text { Histological } \\
\text { pattern }\end{array}$} & \multicolumn{2}{|c|}{ Immunohistochemistry } & \multicolumn{4}{|c|}{ Tumour extract (ng/mg tissue) } & \multicolumn{5}{|c|}{ Receptor bound (fmol/mg protein) } \\
\hline & & & & Gastrin & Other peptides & Gastrin & $V I P$ & Glucagon & $N S E$ & Secretin & $B B S$ & $V I P$ & $C C K$ & $S S T$ \\
\hline 1 & Pancreas & ZES & Solid & +++ & - & 230 & $<1$ & $<1$ & 143 & 0.85 & 0.62 & 0.84 & 0 & $1 \cdot 41$ \\
\hline 2 & Pancreas & ZES & Solid & ++ & - & 167 & $<1$ & $<1$ & 678 & 4.71 & 0.66 & 0.92 & 0 & 0.57 \\
\hline \multirow[t]{3}{*}{3} & Pancreas & ZES & Trabecular & ++ & - & 134 & $<1$ & $<1$ & 72 & $0 \cdot 84$ & 0.71 & $1 \cdot 14$ & 0 & 1.03 \\
\hline & Pancreas & & Solid & ++ & - & 120 & $<1$ & $<1$ & 67 & 1.08 & 0.94 & 0.71 & 0 & 0.56 \\
\hline & Pancreas & & Mix & ++ & - & 80 & $<1$ & $<1$ & 405 & $2 \cdot 31$ & 0.52 & 0.53 & 0 & $0 \cdot 20$ \\
\hline 4 & Liver & ZES & Mixed & + & - & 128 & $<1$ & $<1$ & 95 & 0 & 0.44 & 0 & 0 & 1.46 \\
\hline \multirow[t]{3}{*}{5} & Pancreas & ZES and & Solid & ++ & - & 251 & $<1$ & $<1$ & 687 & 0.91 & $1 \cdot 6$ & $1 \cdot 38$ & 0 & 1.96 \\
\hline & Pancreas & glucagonoma & Mixed & ++ & - & 183 & $<1$ & $<1$ & 1051 & 0.63 & 1.59 & 0.36 & 0 & $3 \cdot 38$ \\
\hline & Pancreas & & Solid & - & Glucagon ++, PP + & 0.62 & $<1$ & $>100$ & 421 & 0 & 0 & 0 & 0 & 0 \\
\hline 6 & Adrenal gland & VIPoma & Solid & - & VIP,++ SST + & $2 \cdot 36$ & $>100$ & $<1$ & 731 & 0 & $1 \cdot 07$ & 0.67 & 1.82 & 0.91 \\
\hline \multirow[t]{2}{*}{7} & Pancreas & VIPoma & Trabecular & - & VIP ++, PP + & $0 \cdot 8$ & $>100$ & $<1$ & 739 & 1.59 & 0.96 & $1 \cdot 24$ & $7 \cdot 56$ & 0.84 \\
\hline & Liver & & $\mathrm{Mi}$ & - & VIP & $0 \cdot 37$ & $>100$ & $<1$ & 8687 & 0 & 0 & $2 \cdot 20$ & 15.9 & 0.42 \\
\hline \multirow[t]{3}{*}{8} & Pancreas & Somatostatinoma & Solid & - & SST ++, PP + & 0.03 & $<1$ & $<1$ & 1818 & 0 & 0 & 0 & 0 & 0 \\
\hline & $\begin{array}{l}\text { Liver } \\
\text { Liver }\end{array}$ & & Solid & - & $\begin{array}{l}\text { SST ++, PP + } \\
\text { SST ++,PP + }\end{array}$ & 0.03 & $<1$ & $<1$ & 141 & $\begin{array}{l}0 \\
0\end{array}$ & $\begin{array}{l}0 \\
0\end{array}$ & 0 & 0 & $\begin{array}{l}0 \\
0\end{array}$ \\
\hline & $\begin{array}{l}\text { Liver } \\
\text { Liver }\end{array}$ & & $\begin{array}{l}\text { Trabecular } \\
\text { Solid }\end{array}$ & - & $\begin{array}{l}\text { SST ++, PP + } \\
\text { SST ++, PP + }\end{array}$ & $\begin{array}{l}0 \cdot 07 \\
0 \cdot 06\end{array}$ & $\begin{array}{l}<1 \\
<1\end{array}$ & $\begin{array}{l}<1 \\
<1\end{array}$ & $\begin{array}{l}1442 \\
1133\end{array}$ & $\begin{array}{l}0 \\
0\end{array}$ & $\begin{array}{l}0 \\
0\end{array}$ & $\begin{array}{l}0 \\
0\end{array}$ & $\begin{array}{l}0 \\
0\end{array}$ & $\begin{array}{l}0 \\
0\end{array}$ \\
\hline
\end{tabular}

ZES, Zollinger-Ellison syndrome; PP, pancreatic polypeptide; SST, somatostatin; VIP, vasoactive intestinal peptide; NSE, neuron specific enolase; BBS, bombesin, CCK, cholecystokinin;,$- 0 \% ;+, 1-10 \% ;++, 10-25 \% ;+++, 25-50 \%$ 


\section{Gastrinoma}

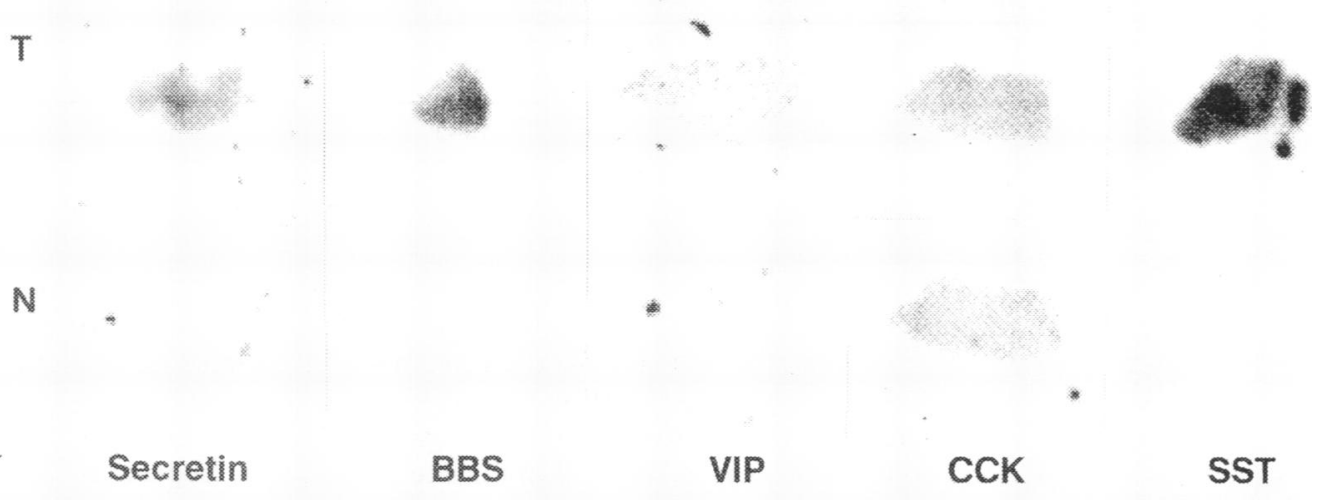

VIPoma

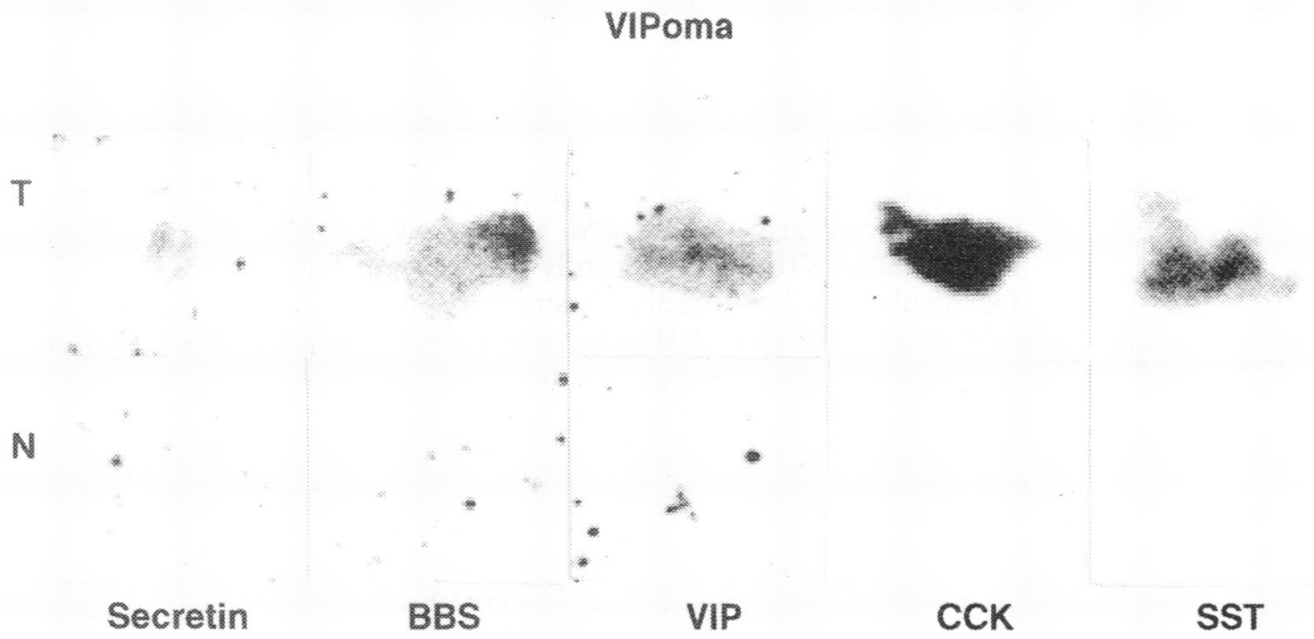

Autoradiographs of tissue section of gastrinomas and VIPomas. CCK=cholecystokin, BBS=bombesin, SST=somatostatin . $T=$ total binding; $N=$ non-specific binding. Original magnification $\times 3$.

receptors for bombesin, but a liver metastasis was negative for the bombesin receptor. With regard to secretin receptor status in VIPomas, only one of the primary tumours from the pancreas was positive. Another primary VIPoma from the adrenal gland and a liver metastasis were negative for secretin. Both the somatostatinoma and the glucagonoma were negative for all five types of peptide receptors studied. By comparison with the corresponding haematoxylin and eosin stained section we found an inhomogeneous distribution of peptide receptors with high labelling (Figure) in high density tumour cell areas.

In this study, gastrin caused an inhibition of labelled cholecystokinin binding to VIPoma sections with little higher half maximal inhibition concentration $\left(\mathrm{IC}_{50}=0.008 \pm 0.001 \mu \mathrm{M}\right)$ than that of cholecystokinin-8 $\left(\mathrm{IC}_{50}=0.001 \pm 0.0008\right.$ $\mu \mathrm{M})$. The $\mathrm{IC}_{50}(0.044 \pm 0.006 \mu \mathrm{M})$ of $\mathrm{L} 365$, 260 was about 40-fold lower than that $(1.74 \pm 0.42 \mu \mathrm{M})$ of lorglumide in those VIPomas. Little competitive binding of ${ }^{125} \mathrm{I}-\mathrm{BH}$ CCK-33 was found with the cholecystokinin-A antagonist. Thus, in the VIPomas tested in this study, the labelled CCK appeared to be bound to the cholecystokinin-B receptor, which was formerly also called the gastrin receptor.
Dose inhibition curve showed a single high affinity binding site for secretin, bombesin, VIP, cholecystokinin, and somatostatin in gastrinomas or VIPomas. The binding affinity and capacity of each kind of receptors in gastrinomas or VIPomas are presented in Table II. In gastrinoma, the affinity $(p<0.05)$ and binding capacity $(p<0.01)$ of receptors for somatostatin were significantly higher than those of the other three kinds of receptors. In VIPomas, the affinity and binding capacity of receptors for cholecystokinin-B are the highest among the five kinds of receptors tested $(p<0.05)$.

\section{Discussion}

This study shows the spectrum of receptors for gastrointestinal hormones on endocrine pancreatic tumours. We show for the first time that secretin and bombesin receptors are visualised in all primary gastrinomas studied. Although the provocation of gastrin release by secretin or bombesin is used as a test in the diagnosis of gastrinoma, ${ }^{10}$ the physiological basis for the provocation has been debated. ${ }^{524}$ Our findings provide evidence for a direct action of these provocative peptides and suggest that the 
TABLE II Affinity and binding capacity of peptide receptors in pancreatic endocrine tumours

\begin{tabular}{|c|c|c|c|c|c|c|c|c|c|c|c|}
\hline \multirow[b]{2}{*}{ Tumour } & \multirow{2}{*}{$\begin{array}{l}\text { Number } \\
\text { of } \\
\text { tumours }\end{array}$} & \multicolumn{5}{|c|}{$K D a(n M)$} & \multicolumn{5}{|c|}{ Bmax (fmol/mg protein) } \\
\hline & & $S S T$ & $B B S$ & Secretin & $V I P$ & $C C K$ & $S S T$ & $B B S$ & Secretin & $V I P$ & $C C K$ \\
\hline $\begin{array}{l}\text { Gastrinoma } \\
\text { VIPoma }\end{array}$ & $\begin{array}{l}4 \\
3\end{array}$ & $\begin{array}{l}2.7(1.5) \\
6.1(2.9)\end{array}$ & $\begin{array}{l}7.5(3 \cdot 0) \\
6.7(4 \cdot 1) \dagger\end{array}$ & $\begin{array}{l}6 \cdot 2(3 \cdot 1) \\
7 \cdot 7(0 \cdot 8)^{\star}\end{array}$ & $\begin{array}{l}6 \cdot 4(2 \cdot 2) \\
7 \cdot 3(4 \cdot 6)\end{array}$ & $\begin{array}{l}\text { NT } \\
0.9(0.7)\end{array}$ & $\begin{array}{l}34 \cdot 3(6 \cdot 1) \\
10 \cdot 2(2 \cdot 9)\end{array}$ & $\begin{array}{l}9 \cdot 5(6 \cdot 0) \\
7 \cdot 8(1.5) \dagger\end{array}$ & $\begin{array}{l}8.9(5.4) \\
5.6(0.4)^{\star}\end{array}$ & $\begin{array}{l}6.9(4 \cdot 1) \\
9 \cdot 2(3 \cdot 7)\end{array}$ & $\begin{array}{l}\text { NT } \\
37 \cdot 2(13 \cdot 4)\end{array}$ \\
\hline
\end{tabular}

Data shown as mean (SD); NT, not tested; ${ }^{\star} n=1 ; \nmid n=2$.

stimulating effect of secretin and bombesin on dispersed gastrinoma cells or cultured gastrinoma cells may be mediated through their receptors on the cells. In addition, the receptors for secretin and bombesin are also present in some of the VIPomas. As both hormones exert stimulating actions on gastrinomas and bombesin receptors can initiate cell proliferation in $3 \mathrm{~T} 3$ cells, ${ }^{25}$ the effects of these peptide antagonists may deserve further investigation.

The gastrinomas and VIPomas tested in this study expressed receptors for VIP. This finding is consistent with the other investigations on VIP binding to endocrine tumours of the pancreas. ${ }^{12}{ }^{15}$ As gastrinoma and VIPoma contain VIP receptors, it is probable that these tumours can also be imaged in vivo with radiolabelled VIP as has recently been shown for insulinoma. ${ }^{15}$ Moreover, identification of VIP receptors in all VIPomas tested in this study suggests that there is an autocrine loop for VIP in VIPomas. It is presently unclear whether the autocrine loop for VIP in VIPomas is a positive, negative or neutral feed back.

Cholecystokinin has been implicated in the control of both exocrine and endocrine pancreatic secretion and growth through specific receptor mediation. ${ }^{26}$ Receptors for cholecystokinin can be classified into two subtypes, cholecystokinin-A and cholecystokinin-B. A recent study using in situ hybridisation showed that the gastrin receptor is identical to the cholecystokinin-B receptor. ${ }^{27}$ The present study is the first to show cholecystokinin-B (gastrin) receptors in human VIPomas with high affinity and binding capacity. This finding may stimulate research into the effects of cholecystokinin receptor agonists or antagonists in VIPoma. In contrast with VIPoma, an autocrine loop is absent in gastrinomas, as cholecystokinin-B (gastrin) receptors are negative in all gastrinomas tested in this study.

As expected, somatostatin receptors were detected in all gastrinomas and VIPomas in this study. In case reports, the somatostatin analogue octreotide has been shown to improve the symptoms and reduce the plasma glucagon concentration in most patients with glucagonoma. ${ }^{10}$ Somatostatin receptors have also been detected in a few cases of glucagonomas. ${ }^{9}$ However, the single glucagonoma reported in this study does not express receptors for somatostatin. The proper estimation of the percentage of glucagonomas expressing somatostatin receptors remains difficult because of the rarity of this tumour. Again, no evidence for autocrine regulation was found in somatostatinoma in this study as indicated by the absence of somatostatin receptors in these tumours. In fact, all types of gut peptide receptors measured in this study were absent in the somatostatinoma and the glucagonoma. Thus, compared with gastrinomas and VIPomas, somatostatinoma and glucagonoma seem to be less hormone dependent.

Altogether, this study displays the spectrum of gut peptide receptors in endocrine tumours of the pancreas. The results of this study may aid in our understanding of the biology of these neoplasms and could be of potential diagnostic and therapeutic interest.

We thank Ms E S M Muller, Ms A H Brommer, and Mr J P Giliams for their technical assistance and our colleagues of the Departments of Surgery and Pathology for providing us with the tissue samples.

1 Hammond PJ, Polak JM, Bloom SR. Miscellaneous tumours of the pancreas. In: Go VLW, et al, eds. The pancreas: biology, pathobiology, and disease. New York: Raven Press, 1993: 997-1007.

2 Jensen RT, Norton JA. Endocrine neoplasms of the pancreas. In: Go VLW, et al, ed. The pancreas: biology,
pathobiology, and disease. New York: Raven Press, 1993: pathobiology,

3 Öberg K. Clinical syndrome, diagnosis and therapy of GIendocrine tumours and MEN-1. In: Singer MV, et al, eds. Gastrointestinal tract and endocrine system. Dordrecht: Kluwer Academic, 1995: 406-16.

4 Lamberts SWJ, Krenning EP, Reubi J. The role of somatostatin and its analogue in the diagnosis and treatment of tumours. Endocr Rev 1991; 12: 450-82.

5 Chiba T, Yamatani Y, Yamaguchi A, Morishital T, Nakamura A, Kadowaki $S$, et al. Mechanism for increase of gastrin release by secretin in Zollinger-Ellison syndrome. Gastroenterology 1989; 96: 1439-44.

6 Gower WR, Ellison EC, Knierim TH, Elkhammas EA O'Dorisio TM, Fabri PJ. Gastrinoma in vitro: morphological and physiological studies of primary cell cultures. Gastroenterology 1990; 98: 936-54

7 Gower WR, Buzogany JA Jr, Ellison EC, Knierim TH, Fabri PJ. Control and gastrin release from gastrinomaderived G cells. Surgery 1988; 104: 424-30.

8 Ellison EC, Gower WR, Elkhammas EA, Elkhammas E, Woltering EA, Sparks J, et al. Characterization of the in vivo and in vitro inhibition of gastrin secretion from gastrinoma by a somatostatin analogue (SMS 201-995). Am $\mathcal{Y}$ Med 1986; 81 (suppl): 56-64.

9 Reubi J-C, Häcki WH, Lamberts SWJ. Hormone-producing gastrointestinal tumours contain a high density of gastrointestinal tumours contain a high density of
somatostatin receptors. $\mathcal{f}$ Clin Endocrinol Metab 1987; 65: 1127-34.

10 Jensen RT, Gardner JD. Gastrinoma. In: Go VLW, et al, eds. The pancreas: biology, pathobiology, and disease. New York: Raven Press, 1993: 931-78.

11 Taylor IL, Mannon P. Gastrointestinal hormones. In: Go VLW, et al, eds. The pancreas: biology, pathobiology, and disease. New York: Raven Press, 1993: 24-49.

12 Virgolini I, Yang Q, Li S, Angelberger P, Neuhold N, Niederle B, et al. Cross-competition between vasoactive intestinal peptide and somatostatin for binding to tumour cell membrane receptors. Cancer Res 1994; 54: 690-700.

13 Estival A, Mouniélou P, Trocheris V, Scemama JL, Clemente F, Hollande E, et al. Presence of VIP receptors in a human pancreatic adenocarcinoma cell line. Modulation of the cAMP response during cell proliferation. lation of the cAMP response during cell prolif
Biochem Biophys Res Commun 1983; 111: 958-63.

14 Svoboda M, De Neef P, Tastenoy M, Christophe J. Molecular characteristics and evidence for internalization of vasoactive-intestinal-peptide (VIP) receptors in the of vasoactive-intestinal-peptide (VIP) receptors in the
tumoral rat-pancreatic acinar cell line AR 4-2 J. Eur $f$ tumoral rat-pancreatic acinar

15 Virgolini I, Raderer M, Kurtaran A, Angelberger P, Banyai S, Yang $Q$, et al. Vasoactive intestinal peptide-receptor imaging for the localization of intestinal adenocarcinomas and endocrine tumours. $N$ Engl $f$ Med 1994; 331: 1116-21.

6 Douglas BR, Woutersen RA, Jansen JBMJ, de Jong AJL, Rovati LC, Lamers CBHW. Influence of cholecystokinin antagonist on the effects of cholecystokinin and bombesin on azaserine-induced lesions in rat pancreas. Gastroenterology 1989; 96: 426-9. 
17 Tang C, Biemond I, Lamers CBHW. Localization and quantification of cholecystokinin receptors in rat brain with storage phosphor autoradiography. BioTechniques 1995; 18: 886-9.

18 Jansen JBMJ, Lamers CBHW. Low binding of BoltonHunter-labelled cholecystokinin-33 to carboxyl-termina CCK-antibodies. F Immunol Methods 1982; 51: 223-30.

19 Ensinck JW, Laschansky EC, Vogel RE, Simonowitz DA, Roos BA, Francis BH. Circulating prosomatostatinderived peptides. Differential responses to food ingestion. f Clin Invest 1989; 83: 1580-9.

20 Schaffalitzky de Muckadell OB, Fahrenkrug J. Preparation of ${ }^{125}$ I-labelled synthetic porcine secretin for radioimmunoassay. Scand 7 Clin Lab Invest 1976; 36: 661-8.

21 Schrenck TV, Moran TH, Heinz-Erian P, Gardner JD Jensen RT. Cholecystokinin receptors on gallbladder muscle and pancreatic acinar cells: a comparative study. Am F Physiol 1988; 255: G512-21.
22 Leroux P, Quirion R, Pelletier G. Localization and characterization of brain somatostatin receptors as studied with somatostatin-14 and somatostatin-28 receptor autoradiography. Brain Res 1985; 347: 74-84.

23 Munson PJ, Rodbard D. LIGAND: Characterizations of binding systems: a versatile, computerized approach. Anal Biochem 1980; 107: 220-9.

24 Brady CE, Utts SJ, Hyatt JR, Dea J. Secretin provocation: gastrin results in various clinical situation. Am $\mathcal{F}$ Gastroenterol 1988; 83: 150-5.

25 Rozengurt E. Bombesin-induction of cell proliferation in 3 T3 cells. Ann New York Acad Sci 1988; 547: 277-92.

26 Johnson LR. Effects of gastrointestinal hormones on pancreatic growth. Cancer 1983; 47: 1640-5.

pancreatic growth. Cancer 1983; 47: $1640-5$.
27 Wank SA, Pisegna JR, de Weerth A. Brain and gastrointestinal cholecystokinin receptor family: structure and functional expression. Proc Natl Acad Sci USA 1992; 89: 8691-5. 